\title{
THROUGH THE PAST INTO THE FUTURE: JEAN-FRANÇOIS BILL - PASTOR, ACTIVIST, THEOLOGIAN 8 JULY 1934 - 12 MARCH 2005
}

\section{Graham A Duncan ${ }^{1}$}

University of Pretoria

graham.duncan@up.ac.za

\section{Tinyiko Sam Maluleke ${ }^{2}$}

University of Pretoria

\section{ABSTRACT}

Jean- François Bill was a significant church leader of the second half of the twentieth century. He was born, raised and educated in South Africa, and he lived, worked and died in South Africa. He possessed a multi-cultural identity. He had a rare academic ability but was no academic recluse. His varied and intensive ministry was marked by committed, responsible, constructive engagement. He was a convinced yet reasonable ecumenist with a powerful social conscience who offered a great deal to the field of theological education. He had a vision of a responsible church which was responsible in a practical way by working through the live issues of the day. This would be a church which would strive for authentic unity and be the leaven in the lump of the world.

Keywords: Jean-François Bill; church leader; theologian; South Africa

1 Emeritus Prof. Graham Duncan was Head of the Department of Church History and Church Polity at the University of Pretoria.

2 Prof. Tinyiko Sam Maluleke is professor of African Spirituality and Culture and special adviser to the Vice-Chancellor on African strategy and internal and external communication at the University of Pretoria.

\section{UNISA}




\section{INTRODUCTION AND EARLY YEARS}

Rev. Dr Jean-François Bill (hereafter Bill) belongs to that generation of exceptional church leaders - few in number - who led the South African church community through the most turbulent years in the history of this country; the nineteen sixties, seventies and eighties. It is the efforts, contributions and sacrifices of this generation of church-struggle veterans, which made the euphoric 1990s possible. Throughout his life, Bill immersed himself in the struggles of ordinary South Africans, always seeking to bear witness to Jesus Christ from the vantage point of the disadvantaged. In his life was combined an amazing desire to be of service to his family, his church, his community as well as the wider world. This may be related to two key influences in his life; his Swiss Vaudois lineage where children were taught to value community service (Harries 2007, 43) and his involvement in the South African struggle for liberation.

Bill was the first born son of Swiss missionaries, Rev. René and Mrs Renée Bill. He was born at Elim Hospital near Makhado in the Limpopo province. He always remembered with fondness his childhood years at the Shiluvane Mission Station (near Tzaneen) and other villages in the Spelonken area, today known as the Limpopo province - the area where his parents worked during his boyhood and young adulthood. As a child there, he played freely with other children in total oblivion to racial differences, basking in the warmth of a closely-knit African rural community. With Tsonga as his first language ('The written Tsonga language was not only controlled by the missionaries, but in a manner that combined endearment, loyalty and possession, they almost owned it' [Harries 2007, 166]), speaking (Swiss) French at home and later learning English, Afrikaans and Sesotho, Bill was from a very early age open to and formed by several cultures at the same time. Throughout his life he embraced and exercised his multicultural identity with a prophetic passion in spite of the countless constraints of both grand and petty apartheid. Long before the birth of the new South Africa, Bill heralded in the new South Africa through his own life - yet accomplishing all these without denying his Swiss roots, his faith as a Christian, his calling as pastor and his Tsonga heritage. He was a world citizen who could not be contained exclusively and completely in any one of his cultural heritages. Born of missionaries, destined to be a missionary who could return home on the completion of his active service, as arranged for him to be at the Lausannebased Département Missionaire, Bill had become used to 'sticking around' (Spong 2006); it is something he did throughout his entire vocational life. Here was a white missionary who was truly at home among disadvantaged black South Africans. He embraced black culture and took on all the issues that resonated with black aspirations in both church and society. 


\section{EDUCATION AND THEOLOGICAL FORMATION}

Bill attended Capricorn Boarding School in Polokwane and completed his primary and secondary schooling at Boys' High School in Pretoria where the reality of South African racial segregation slowly but surely dawned on him. In response to a call to the ministry of the church, Bill went to Rhodes University to study and to develop his formation. His first posting with the Tsonga Presbyterian Church in South Africa (TPCSA) was as chaplain to the students at Lemana Teacher's Training College founded by the Swiss mission. ${ }^{3}$ His contact with students from the beginning of his ministerial career sensitised Bill to the radical side of black aspirations of the disadvantaged, and the transformation of the country.

In 1964 Bill was awarded a study fellowship by the highly regarded Chicago Theological Seminary in the USA. In Chicago, Bill, who was steeped in the democratic traditions of his native Switzerland, gained a glimpse of both the promises of multiracialism and the devastating effect of racism. In this liberating context, his thinking developed on the lines of discerning the implications of anti-racism and non-racism for the church. He became convinced that only a united church could bear witness in a divided world. In 1965 he completed his Master of Theology degree after completing an incisive thesis titled: The responsible selfhood of the church: A study of the Tsonga Presbyterian Church. Three things are evident in this study:

1. The absence of biographical references.

2. The enthusiastic optimism about and commitment to radical church unity.

3. The suggestion that the church is like a mustard seed and that if society is the flour, the church is the yeast - 'the leaven in the lump'.

The study reveals Bill's view of the reciprocal, dynamic and even dialectical relationship between church and society. It also reveals a deep understanding of the mission and mandate of the church in general and the South African church in particular. The study focused relentlessly on the topic of unity, proposing a church unity model and a church unity process for the South African family of Presbyterian churches. What is particularly noteworthy is the palpable optimism of the words with which Bill concluded his thesis:

One thing seems certain. God works in strange and quiet ways, often baffling to our minds, often foolish in our judgement. The parables of the mustard seed and of the leaven in the lump express this. And we believe that just as those few apostles revolutionised the Roman

3 The Mozambican leader, Eduardo Mondlane's formal education began in Swiss Presbyterian schools, when a Swiss missionary took on the responsibility for his education, welfare, and development. He trained as a teacher at Lemana Training College at Njhakanjhaka village, Elim (McQueen 1998). 
Empire, so it may be that small beginnings...could lead to revolutionizing and transforming the situation in South Africa...It is the responsible church which will act as ferment in society, as the leaven in the lump, and it is our hope that the Tsonga Presbyterian Church may grow into responsible self-hood even as it moves into this new venture of forming a United Presbyterian Church. (Bill 1966, 208)

From the above quotation, we also discover the basic theological principle which formed the pole around which Bill built his idea of what the church should be - 'the mustard seed', 'ferment in society' and 'the leaven in the lump'. This idea consumed his mind throughout his life. While teaching at FEDSEM, Bill used this idea to inspire his students, and when he was Moderator of the EPCSA Synod, he continued to promote this idea. This was to lead him into problems with both his church and the national and Gazankulu governments in later years.

While in Chicago, Bill became influenced in his thoughts and work by the Civil Rights Movement, particularly the writings, speeches and actions of Martin Luther King Junior and Malcolm X. On his return to South Africa, his ministry became much more critical of South Africa's racially based government. His theological horizons were widened by the works of anti-Nazi theologians such as Martin Niemoller and Dietrich Bonhoeffer. Already in these early years, the apartheid government was beginning to mark Bill out as a 'trouble-maker' (Yates and Chester 2006 in the title of their book on Michael Scott) warranting special 'attention'.

\section{THE SON OF HIS FATHER}

Bill's radicalism did not just emerge from his exposure to education and to the church. He followed in a tradition established by his father, Rev. René Bill, who had raised critical questions as early as 1947 regarding Swiss Département Missionaire (DM) policies relating to indigenous peoples (Jeanneval, Monier-Gerard and Peclav 2011, 163). Bill senior argued that missionaries should become co-workers in mission. In 1951, Bill senior in Commission Administrative argued for the transfer of responsibilities with the aim of establishing an authentic local church 'rooted in South Africa, materially and administratively' (Jeanneval et al 2011, 164). Such thinking was influenced by international mission trends in the early 1950 s, especially Lesslie Newbigin's challenge to create independent local churches where missionaries become servants of the churches in which they serve. This was related to Newbigin's concern for independence in local churches 'when Western churches provide resources that can thwart local initiative, and independence that implies selfsupport' (Stults 2009, 13). As with many mission issues globally, the relationship with the sending body and the receiving body was fraught with tension relating to money, personnel and power (Van der Water 2015, 16-19). The DM in Switzerland provided missionary salaries and controlled the financial administration of the mission. Bill senior began raising issues which Bill would later pursue. 


\section{SERVICE TO THE EPCSA - HIS CHURCH}

The theme of Bill's Master thesis already signalled at least two passions which were to stay with him for the rest of his life, namely, the quest for practical ecclesiology (practical Christianity) and a vision for radical ecumenism (church unity). When in 1962, the Swiss Mission in South Africa handed over what was then only a 'Swiss mission' to the local people, in the process renaming it the Tsonga Presbyterian Church (TPC), the daunting tasks of giving shape, content, structure and vision to the new entity remained (see also Maluleke 1993, 1994). The execution and facilitation of these tasks were to fall on Bill's capable shoulders. The 20-year period of 1966 to 1986 - arguably his prime years - saw Bill accomplish, amongst many others, the following significant achievements for the EPCSA, most of them almost singlehandedly:

1. The articulation and consolidation of structures for the church.

2. The renaming and re-imagining of the church from the blatantly ethnic and tribal Tsonga Presbyterian Church to the more ecumenically inclined Evangelical Presbyterian Church in South Africa (EPCSA).

3. The drafting of a proper constitution for the church.

4. The creation of a pension fund for black ministers.

5. The creation of parity of salary scales for black and white ministers in the EPCSA.

6. Pioneering church investment through the identification and purchasing of the prime property of Portland Place in Braamfontein.

7. The drafting of a worship liturgy for the church, Magandzelelo eKerekeni.

8. The cultivation of a prophetic voice for the church in the most difficult period in the history of both church and country - leading to and including his imprisonment for nine months and the imprisonment of his son Charles.

9. The promotion of theological education, including postgraduate theological education, for blacks in the mission churches - and serving as a lecturer between 1971 and 1979.

10. The cultivation of an ecumenical spirit in the church, encouraging and ensuring its continued membership in local and international ecumenical organisations.

11. The theological basis for, as well as the envisaged processes of, the ongoing Joint Commission for Unity and Renewal (JCUR) created in 2001 to heal the 15-year old split within the EPCSA,.

In all of this, Bill conformed to Harries's $(2007,35)$ conviction that Swiss missionaries 'were propelled by... an indefatigable curiosity and organizing spirit'. The sheer range of projects conceptualised, led and executed by Bill within the EPCSA is 
formidable. His long shadow is cast over all the key areas in the development and maturation of the church.

Moreover, Bill was no narrow-minded missionary ecumenist concerned only with the legacy of Swiss Mission in South Africa. His thesis contained an incisive proposal for the uniting of the four Southern African Presbyterian churches, the Bantu (Reformed) Presbyterian Church, The Tsonga Presbyterian Church, the Presbyterian Church of Africa and the Presbyterian Church of Southern Africa to form what Bill called the 'United Presbyterian Church of Southern Africa'. This was no timid proposal based on some elusive probabilities and fantasies. In it, Bill conceptualised the new structures and considered all of the possible problems and how they could be overcome. Furthermore, Bill was convinced that he would, upon his return from Chicago where he studied, return home to witness the creation of the United Presbyterian Church of Southern Africa. He had no doubt that, having accepted in principle a document containing the draft basis for the union, the Tsonga Presbyterian Church (as the EPCSA was known then) would become part of the new church. The last chapter of Bill's thesis optimistically describes the sister church of the EPCSA Igreja Presbiteriana de Mocambique (IPM). Jan van Butselaar $(1984,1)$ cited in the sermon preached at Bill's funeral by Prof. T.S. Maluleke at Polokwane, 19 March 2005 (Maluleke 2005b), describes the same church as 'une petite Église africaine issue du zèle des missionnaires noirs et des efforts d'une mission européenne' (a small African church born of the zeal/efforts of black missionaries and a European mission). But smallness is also the chief characteristic of the IPM's South African counterpart, the EPCSA. Despite its smallness, despite its slowness to change and resistance to transformation, Bill never gave up on the small Tsonga Presbyterian Church whose overwhelming membership, the Tsonga, were themselves often marginalised in the ethnic politics of apartheid South Africa. As a consequence, the Vatsonga were prone to low esteem and even self-hate. Therefore, the EPCSA was not only a small church in size, its overwhelming membership was a people often made to feel small. The majority of the Vatsonga had been migrants and had not been in the (new) South Africa for long when the Swiss missionaries arrived in the second half of the nineteenth century.

Perhaps his ecclesiastical achievements can best be summarised in words spoken at his funeral: '...the transformation of the Tsonga Presbyterian Church from a narrowly ethnical identity into the more ecumenically attuned Evangelical Presbyterian Church...must go down as one of Bill's seminal achievements in his own church' (Maluleke 2005a).

With regard to the parity of stipends, Bill believed that 'spiritual integration demanded material integration as well' (Jeanneval et al 2011, 167); hence the establishment of the Vutirheli fund to assist African pastors. The issue reared its head again in 1972 when two mission families, the Bills and the Schneiders, sent a letter to all mission staff seeking their support for a call to the church to fix a 
common basic stipend for all church workers (University of the Witwatersrand, William Cullen Library 1084 File SIO [5], letter by Catherine and Theo Schneider and Molly and Jean-François Bill, 'To all fraternal workers in the TPC', Bill and Schneider December 1972).

Bill considered himself a Mutsonga who served the Tsonga Presbyterian Church not as a missionary, but as an indigenous pastor. While it made perfect and practical sense at the time, the fact that the Département Missionaire (DM) in Lausanne considered him a 'Swiss missionary' and an 'envoy' must go down as the most inaccurate designation anyone could ever bestow upon him. Similarly, while the local church had clear ideas about missionary versus local mission relationship patterns, these distinctions collapsed in Bill and became blurred. Local people never considered nor called him a Moneri - a term reserved for missionaries. Without denying the affection that lay behind the nick-name Xibilana (Bill Junior) this naming had many functions. It was a subversive appellation. It was a name subversively and deliberately inserted in the space normally occupied by the name Moneri. This is the overwhelming sense in which ordinary people would refer to him as Xibilana. In calling him Xibilana, ordinary church members were refusing to designate him a Moneri and thereby considering him a missionary. There were the Moneris and there was Xibilana. Clearly, Bill's relations with both the DM and the local church were essentially misnamed and therefore repeatedly misread, leading to many misunderstandings.

\section{ECUMENICAL, COMMUNITY AND POLITICAL ACTIVITIES}

Apart from the traditional activities and daily duties as minister and student chaplain, Bill initiated and ran, in the nineteen-sixties already, a vast feeding scheme in the Zoutpansberg area where people were suffering and children were dying. This reflects a national trait, for according to Harries $(2007,35)$ Swiss evangelists 'were propelled by....an indefatigable curiosity and an organizing spirit' that was evident throughout Bill's life. Vaudois children were also 'taught to appreciate community service' (Harries 2007, 43). At such times, parents were feeding their children with wine made from milala palms to put them to sleep so that they would not cry for food night and day. When in 1968 the Church moved him to Pretoria, Bill experienced new levels of frustration as he came to experience more and more the effects of the apartheid system on community life. As a white person he was, for example, not automatically allowed to live among the people whom he served, leading to endless and frustrating applications and negotiations for apartheid-era permits. But during that time, Bill was brought into contact with the wider African church - attending conferences in such places as Abidjan and Nairobi. These contacts gave him not only a larger view of the church in Africa, but he was also able to get a glimpse into 
independent Africa, inspiring him to redouble his efforts in working for political independence in South Africa.

At that time (1967-1968), Tsonga Presbyterian students were trained at Morija in Lesotho. Bill, Chair of the TPC Theological Education Commission, expressed reservations concerning this arrangement on the grounds of the poor quality of the training and student access to Lesotho. The birth of the ecumenical Federal Theological Seminary (FEDSEM) in the Eastern Cape precipitated a change of training venue and initiated a more radical approach to the social and political role of the church in South African society (Jeanneval et al 2011, 180).

As theology lecturer at the Federal Theological Seminary (FEDSEM) in Alice (1971-1979), where he eventually became Principal of St Columba's College, Bill became an asset for the wider ecumenical family. There he was lecturer to many of the current leadership of the so-called historic-mission churches. FEDSEM was a community of people of all races at a time when this was not tolerated. Contacts with militant Fort Hare students, through their student organisation SASO, and clandestine meetings with student leaders such as Steve Biko, challenged Bill deeply and made him even more radical in his views. In 1973, FEDSEM was expropriated by the government (Denis and Duncan 2011, 101-116). In this process, Bill played a decisive role in the Seminary's response to the offer to purchase the Seminary from Fort Hare University prior to expropriation. He believed in a proactive approach based on moral criteria which would express the racial solidarity of the FEDSEM community:

We are faced not merely with the prospect of a commercial transaction, but are confronted with a moral issue. And in this issue any material loss which the Churches might sustain, will be far outweighed by the moral gain of a firm stand. It seems to me that the Blacks in our Churches are waiting to see whether the Churches will resist this evil. Are our White power structured Churches prepared to listen to what the Blacks are saying? And I hear them saying: The Churches can have no part in this evil. To collaborate in this would be a betrayal. If it must happen, then let it happen without the co-operation of the Churches. Let the Government do its own dirty work. Thus it seems to me that the Churches stand to lose their integrity if an equivocal reply is not given to Fort Hare. We cannot continue to be bullied. We cannot continually be on the defensive. We must now take the offensive, and show once and for all that the Churches which so often deplore the injustices in this land, and particularly the injustice of removals, are now prepared to resist such injustices, particularly when the Church's Institution is itself threatened with removal. (Speech, Bill to Seminary Council, 4 August 1972 in Cameron 1984, 116-117)

South African churches stood together as one against this: challenging the decision, but eventually the seminary had no choice but to move; first of all to Umtata, then to Pietermaritzburg, where ironically, FEDSEM died a slow and painful death in the new South Africa.

Bill was instrumental in the formation of Albert Luthuli College at FEDSEM when St Columba's (Presbyterian) and Adams United (Congregational) Colleges 
united in 1977 while 'the Seminary is still in pilgrimage wandering in the wilderness' (Speech, Bill to Seminary Council, 4 August 1972 in Cameron 1984, 116-117). This demonstrates his ecumenical commitment and was quite an achievement since in 1960 the Presbyterians had specifically decided to train their ministers separately from the Congregationalists (Denis and Duncan 2011, 135). This demonstrated his fundamental belief in people: '.. the Albert Luthuli College does not now have any buildings. This, I believe is significant for it means that we inaugurate a people in community and not a structure in concrete' (Bill 1977, 1). In a sense, he was an Africanist in his approach to theological education. Noting the debt to the European heritage of theological education, he was clear that:

...our task now is to take seriously both the context in which we live and the gospel we both believe and proclaim, so that the expression of our beliefs, the style of our worship the structure of our institutions and the patterns of our ministry and witness will be authentically of Africa. (Bill 1977, 4)

However, Bill did not underestimate the problems, for in the South African context:

... any attempt to indigenize or Africanise the church is regarded with suspicion, and seen as yet another attempt to emphasise the differences between the various groups in South Africa and thereby to strengthen the basis on which the policy of separate development stands. (Bill 1966, iii)

But this was a matter of 'responsibility' for the church which 'seeks to be faithful by becoming truly indigenous, not just in a cultural sense, but in a theological sense, by being responsible in the situation into which God has called it' (Bill 1966, 178). He chaired a sub-committee of the Seminary Council which was charged with the study of the Warden Report on the unification of the Seminary, and which set the seal on the future integration of the colleges into a united structure (University of Fort Hare, Federal Theological Seminary, Report of the sub-Committee for the Administration of the Seminary presented to the Council on 26 March 1980). His ecumenical commitment in theological education was maintained even after he left to become director of theological education at the SACC.

It was at this time that his gifts as a 'visionary ecumenist' came to the fore. It is not possible to write the history of the ecumenical movement in this country without reference to his name and his contribution; especially the emergence of an ecumenical consciousness in the EPCSA. At no time was Bill's dream of a United Presbyterian Church more reachable than now. Two of the four Presbyterian Churches united in 1999. And yet, at no time was this dream further from being realised. The missing links in the realisation of the dream of a United Presbyterian Church are none other than the Evangelical Presbyterian Church and the Presbyterian Church of Africa, which are themselves paralysed by internal disunity. But Bill offered a 'wayforward' - a parting gift - when he put forward an elaborate proposal for a vehicle that will resolve this internal disunity; the Joint Commission for Unity and Renewal. 
Bill was also responsible for the identification of, investment in and alterations to the current South African Council of Churches offices; the elevation of the status of theological education including postgraduate studies for black students in all the historic mission churches. He did everything he could for the sake of witness and unity in the church universal.

His entire approach to ministerial formation in the face of the evil of apartheid transcended denominational differences:

The only power that can ultimately overcome these forces is the power of God which is promised to us by his Son and given by his Spirit. We must equip our minds - we must become wise, we must learn to think out clearly the implications of our faith and to proclaim courageously to all those who are prone to follow false ideologies and worship false gods, the love and justice, the judgment and grace of God. We must equip our bodies - we must become strong and whole. We need self-discipline. We need to learn redemptive suffering and be willing to serve rather than be served. We need to know that to live we must be prepared to die. We must equip our souls - we must be holy, not pious but truly holy. We need to be filled with love for God and for our fellowmen, not sentimental love but the kind of love which is humble, dependable, dedicated, honest, the love which strives for justice and righteousness. We need to be rooted in our Lord and Master and bear the fruits that benefit those who call themselves by the name of Jesus Christ. (Bill 1977, 6-7)

Here we can see a clear Bonhoefferian influence in his thinking of the implications of 'Costly Discipleship': 'When Christ calls a man he bids him come and die' (Bonhoeffer 1959, 7); and costly moral leadership where like Bonhoeffer, Bill's spirituality was also closely related to his morality (Kelly and Nelson 2003, ix).

When it was his turn to become Seminary President, the Council decided in the midst of their new building programme to continue the presidency of Simon Gqubule. Bill bore this decision with great grace despite the deep hurt he felt. While teaching at FEDSEM in Pietermaritzburg, Bill became a founding member of the Pietermaritzburg Agency for Christian Social Action (PACSA), and was its first chairperson. It is interesting to note that Bill saw a clear link between theological education and social justice activities (Nuttall 2002, 12). On Bill's death, Khoza Mgojo (2005), President of the SACC, said of him: 'We used to travel together at a great risk, visiting our comrades who were in exile in the neighbouring countries beyond the borders of South Africa. François Bill had a great heart for humanity. He lived his beliefs. He served the Federal Theological Seminary with distinction.'

Bill's deep social concern can be discerned in a project he became involved in whilst the Seminary was still at Alice. This was 'A Pilgrimage of concern for Family Life' which was an attempt to draw attention to the plight of African families subjected to the inhuman legalised migratory labour system. For Bill, the pilgrimage was 'a kind of prophetic proclamation' (Bill and Russell 1973, 19). It began on 16 December 1972, the Day of the Covenant and its significance was not missed: 
...we felt that we needed to go back to the basis of our faith - that we are a covenant people... Through this pilgrimage we want to draw the attention of the Christians of this land that it is God who makes this covenant and wants us to keep it on His terms... That is why we began at the Bible monument in Grahamstown on the Day of the Covenant, re-interpreting this idea of the covenant. (Bill and Russell 1973, 19)

The purpose of such demonstrations is often questioned in terms of their value and objectives. Here, it was quite clear that this pilgrimage was not undertaken to demonstrate anything to black people, for they already knew the effects and impact of the migratory labour system. Bill had already determined that from black people themselves who lived in the Transvaal: '... what choice have we got? In order to survive we must go to work; in order to find work we must go to the city; in order to go to the city, we must go as migrants' (Bill and Russell 1973, 21). The purpose is cogently stated by Knighton-Fitt $(2003,167)$ : 'If ever there was a white conscientising activity, this was it!' As for the effect of the walk it is difficult to ascertain, although Knighton-Fitt $(2003,170)$ rather depressingly asserts: 'The Pilgrimage caused only a temporary little wrinkle in white consciousness.' Perhaps so, but that knowledge would not have dissuaded the participants from having undertaken the project, for conscientisation is a lengthy and complex process.

While a committed member and minister of the EPCSA, Bill's vision of the one, holy, Catholic and Apostolic Church was not restricted to his work in theological education. From his student days, he was firmly convinced that an indigenous church was one which was not fettered by the ties of denominationalism:

I have become more and more convinced that a truly indigenous church is a church which in a given situation is responsible - responsible to its nature and being as the body of Christ and responsibly fulfilling, within that particular situation, its mission of reconciliation. (Bill 1966 iv)

He was deeply aware of the risks of a form of reconciliation between the various racial, cultural and language groups which would result in a token assimilation rather than 'be the embodiment of genuine reconciliation and community' (Bill 1966 179). This could only be achieved by facing up to the realities and expressing 'itself in and through the contingencies of economic and political structures, and of all human relationships' (Bill 1966, 182) and this the church in South had failed to do. He was trenchant in his rhetorical critique:

Can we say we are one in Christ if our oneness is confined to the church, but disappears when we are in the world?...Is the church a sugar-coated pill that sweetens the bitterness we experience in our relationships or is it the salt that stings in healing the wounds of our estrangements? (Bill 1966,184)

Bill would be able to identify with Spong $(2006,141)$ a non-indigenous long-term missionary: 'I chose black companionship as much as I could. I chose to align myself with their cause and aspirations. This did not mean I abandoned whites. I 
challenged and informed. I pleaded and cajoled.' Interestingly, Bill linked the need for communication with the need for new platforms of community (Bill 1966, 191203). He debunked the idea that language was an insuperable barrier to reconciliation and unity by quoting Mehl, '...communication has not only to do with language often it even transcends it'! (Mehl quoted in Kraemer 1956, in Bill 1966 193).

In 1980, Bill was appointed Moderator of the EPCSA, and he was re-elected for the constitutional three terms - an honour which he treasured deeply. The 1980s signalled somewhat of a radicalisation of the EPCSA in which Bill was clearly a participant. Jeanneval et al $(2011,129)$ describe it as 'a radical wing came into power within the TPC/EPCSA in the 1980s, and even the Church's Moderator at this time, Rev. Bill was himself deeply involved in the church's struggle against apartheid'. Bill's negative attitude towards apartheid was a sensitive issue for the EPCSA since some of its leaders were themselves embroiled in the apartheid system, aligned with the homelands policy and, consequently, of forced removals. This had serious implications for the EPCSA's relations with the DM for 'the links that the Swiss Mission [DM] and the TPC had with the Tsonga elite made it virtually impossible to take a stand against the [forced] removals' (Jeanneval et al 2011, 131). This issue would persist as the EPCSA remained complicit with the Gazankulu government. Its General Secretary, Rev. Sydney Ngobe, was a board member of the Gazankulu Development Corporation.

Between 1981 and 1986, Bill occupied a number of positions in important organisations fighting for justice and better education for all: the Association of Southern African Theological Institutions (ASATI); the African Scholarship Programme (ASCOP); and the Alliance of Black Reformed Christians of South Africa (ABRECSA) of which he was a founding member in 1981. ABRECSA was formed 'to oppose the fragmentation of churches on racist lines and to institutionalise the Reformed confessing movement in South Africa' (Jeanneval et al 2011, 202, n.87). In 1983, at a time when relationships between the Inkatha Freedom Party and the growing United Democratic Front (strongly supported by FEDSEM, by this time housed in Natal) were deteriorating, Bill in his capacity as General Secretary of ABRECSA, organised a field trip for the delegates to its annual conference at KwaNzimela in Zululand. This group included a number of overseas visitors. The purpose of the trip was to see first hand the effect of forced removals on poverty, disease and hunger. The chief minister Gatsha Buthelezi sent a delegate, Dr Denis Madide, to greet the delegates. Bill rejected this move by claiming that this could not happen without the approval of the ABRECSA executive, since this would be tantamount to recognising a Bantustan government. A serious degree of threat was perceived and the conference left KwaNzimela in the middle of the night (Maré and Hamilton 1987, 198). Bill was not to be compromised or to lead others, especially representing the international ecumenical community, into a compromising situation at a very delicate period in the struggle against apartheid. 
Bill was a member of the General Assembly of the World Alliance of Reformed Christians (WARC) which condemned apartheid as a heresy at its council meeting in 1982. He also became a member of the World Council of Churches (WCC) Central Committee. In 1984, Bill was awarded an honorary doctorate by the University of Lausanne, Switzerland, in recognition of his contribution to ecumenism and prophetic witness against apartheid. Yet, he remained firmly grounded in matters of national concern. He was part of a group of church leaders that formed at Mogopa in the North West Province, where one of the most brutal forced removals took place, to express solidarity and offer comfort (Lubbe 2014 287).

His final term as moderator of the EPCSA was rudely interrupted when on 20 June 1986 Bill was arrested by the apartheid police. In his capacity as General Secretary of ABRECSA, Bill had been involved in preparing a liturgy to commemorate the $10^{\text {th }}$ anniversary commemoration of 16 June 1986 (Robertson 1999, 14). It was quite explicit in its use of scripture to support the oppressed in South Africa. The rationale stated bluntly:

We have continually prayed for the authorities, that they may govern wisely and justly. Now, in solidarity with those who suffer most, in this hour of crisis we pray that God in His grace may remove from His people the tyrannical structures of oppression and the present rulers in our country who persistently refuse to heed the cry for justice, as reflected in the Word of God as proclaimed through His church both within this land and beyond. (SACC 1985, 3)

Bill had also been involved in the preparation of Kairos liturgies for Good Friday and Easter Sunday (Kairos Theologians 1986) based on the Kairos Document. These liturgies with sermon outlines made significant use of the Psalms. The authorities found this to be very provocative and detained him without charge. He was accused of treason and communist activities. These charges were dropped. Yet he was incarcerated for a further six months.

Nowhere did the metaphor of the mustard seed and yeast fit him more aptly than at this time. There he was tortured and derided for being neither white enough nor black enough and urged to make an intelligent choice and become white. His torturers told him that the blacks with whom he identified had neither love nor respect for him. They even used the end of his term as moderator as a sign that the blacks had had enough of him. He was made to feel small, rather like a mustard seed. When he was visited by the Swiss consul he appeared manacled hand and foot, his wife Molly recalled. He was shaken but not broken. After being held for nine months in detention with neither charge nor trial, he was released (Robertson 1999, 150). During that time, his wife, Molly found great support among the nonracial congregation of St Antony's Pageview while she could not attend the EPC in Tshiawelo. On his release, Bill and Molly travelled to Switzerland where they promoted the struggle against apartheid and Bill called for economic sanctions when he addressed the Fédération des Églises Protestant de Suisse. 
Following the short stint in Switzerland, Bill returned to take up a position as General Administrative Secretary of the SACC in 1988. While at the SACC, its offices at Khotso House were almost totally destroyed by a bomb, a dreadful act of apartheid agents that affected Bill deeply. In the aftermath of this event, he was instrumental in the identification and construction of the new SACC building, including the chapel. He later worked as Administrative Manager of the Alexandra Health Centre and as Director of a rural development NGO, Funda-Ithuseng. The end of apartheid was, of course, the other dream of Bill which was fulfilled in his life time.

Sadly, this was a troubled time in the Bills personal life as their marriage disintegrated and they divorced. Privately, Molly attributed this to the trauma Bill experienced in detention. Bill remarried. Molly did not.

Bill's troubles were not yet at an end, however. The South African Council of Churches (SACC) convened a convocation of Churches in May [1988] that launched a national 'Standing for the Truth Campaign' with the initial objective of releasing political prisoners (Allen 2006, 293). Various churches took up the call to join Standing for the Truth, such as the closely related Reformed Presbyterian Church in Southern Africa (RPCSA, General Assembly proceedings, 1988, Min 6143 [7]:30): 'Supports the resolution of the SACC convocation to launch a standing [sic] for the Truth Campaign...' However, the Evangelical Presbyterian Church faced internal difficulties regarding its response to apartheid, as we have seen. By this time it had a much younger cadre of ministers who had been recently trained in more radical, political, anti-apartheid theologies at FEDSEM. In the period 1988-1989, the EPCSA divided into the 'Standing for the Truth' (SFT) and the remainder of the denomination. The impact of the Kairos Document was being felt. Jeanneval et al $(2011,161)$ attribute the dispute to three main causes: first, the political role of the church in the Gazankulu homeland; second, theological and ecclesiological interpretations concerning the exercise and division of power within a church; and third, personal rivalries. The third aspect may well be true; if so, this is a simplistic interpretation of a complex matter. The issues were, in one sense, generational. While older people had resigned themselves to the homelands policy, younger people in the 1980s were pressing for radical change. Theologically and anthropologically, South Africa was influenced by Biko's (2004 [1978]) Black Consciousness philosophy and Black Theology propounded by scholars such as Itumeleng Mosala, Buti Thagale and Takatso Mofokeng (1986). In all this, Bill stood apart from his Swiss roots.

All of this had repercussions for him personally. In 1989, Bill was expelled from the EPCSA because he had taken up a post with the SACC as Director of Administration in 1988. It is ironic to note that he had already left the SACC by the time of his expulsion. In 1991, he was declared to be no longer a member of the church, though he was a key member of the SFT. Despite the continuing Joint Commission for Unity and Renewal (JCUR) created in 2001 to heal the 15-year old split, the EPCSA was the initiative of Bill. 


\section{AN OUT OF PLACE KENOTIC WITNESS}

In his autobiography Edward Said, the late renowned professor of English and a post-modern scholar at Columbia University in New York, submits that throughout his life he has, owing to his multi-culturity, always felt out of place. An American citizen, born and formed in Palestine and Egypt, not as a Muslim but as a Protestant, yet completing his education up to $\mathrm{PhD}$ level in the USA, fluent in both English and Arabic, Said speaks of his sense that he was possessed of many identities. The following were some of the questions and remarks he has had to deal with throughout his life as people tried to reduce his identity to one familiar category:

"What are you?"; "But Said is an Arab name"; "You're American?"; "You're American without an American name, and you've never been to America"; "You don't look American!"; "How come you were born in Jerusalem and live here?"; "You are an Arab after all, but what kind are you? A Protestant?" (Said 1999, 5)

Bill could relate to this. His attempts to navigate the identities of being white in South Africa, being Swiss, being pastor and being a Mutsonga, necessarily meant that he felt and was made to feel constantly out of place - a member of a permanent minority. Many urged Bill to take the easy route of choosing the obvious and easy identity - Swiss. Others advised Bill to become a white South African with a Swiss background - like many other children of missionaries had apparently done. But what kind of Swiss citizen is this who is born in Elim Hospital and grows up at Shiluvane? What kind of a white South African is this who spoke Tsonga better than many people born of Tsonga parents? What kind of white South African was this who clearly loved blacks well beyond and outside of the master-servant relationship paradigm? What kind of a Mutsonga was this who was white? These questions circled and followed Bill throughout his life. Because he refused to take the easy route, Bill was often out of place. He was often made to feel out of place. But being out of place is also a site for mission and ministry. Bill chose to exercise his ministry in that out-of-place space. He refused to jettison any of his heritages. He refused to surrender his values, his faith and his hopes. Should we be surprised then, that Bill found himself 'out-of-place' and forgotten even in the new South Africa? Yet, Bill spent - literally spent - his life in service, witnessing for Christ and heralding His kingdom.

What all these things do is to reveal Bill not only as a visionary ecumenist, but as a practical and committed church man. It also reveals that Bill displayed an amazing life-long consistency of loyalty - loyalty to the church, to cherished ideals and a loyalty to God. Bill led a life of transparent integrity and a purposeful vocation. He did everything he could for the sake of witness and unity in the church universal.

At the time of his passing away, Bill was involved in a number of small business and community projects in the Polokwane/Tzaneen area. Though officially retired some time earlier, Bill never stopped serving; he never stopped learning; never 
stopped working - working for a better life for all; and most importantly, he never gave up. He was indomitable. His students and colleagues will remember him by the nickname they gave him - Zukwa - a tribute to his accessible, helpful and simple personality and lifestyle. Within his church, the EPCSA, he was affectionately known as XiBilana (Bill Junior) - both a name of endearment and deference to Bill Senior, his father the Rev. René Bill. Many times Bill would suggest - in jest - that his full and proper surname was Bilankulu - a very common name among the Vatsonga. Bilankulu was his assumed and adopted surname in order to give expression to his Tsonga heritage.

\section{CONCLUSION}

Bill was one of a genre of missionaries who emerged during the second half of the twentieth century. His ministry reflected the values of one such as the Lutheran, Wolfram Kistner who 'placed a strong emphasis on those who were suffering injustices, who were struggling for righteousness, those who were living on the periphery of society' (Makue 2008, ix). His involvement in the Standing for the Truth movement in his own church was related to the suffering of others. Like Kistner, standing for the truth, he never lost sight of those suffering the receiving end of an unjust societal, political and economic system. He constantly stood alongside the oppressed in his unflinching commitment to working with the marginalised in the pursuit of betterment. It was an approach that was anchored in biblical notions of justice and rooted in a conviction that, guided by the praxis of Jesus, the marginalised must lead the struggle against dehumanisation and oppression (Maluleke 2008, xiv). The truth he upheld was as biblical as it was unpleasant for many (Phaswana and Lilje 2008, xi). In terms of his ecumenism, again like Kistner, Bill's life and work challenge us to abandon the narrow divides of denominationalism and to become a truly ecumenical church (Phaswana and Lilje 2008, xi).

Perhaps Bill's legacy can be summarised in the words of Bernard Spong (2006, 369-370), a colleague at the SACC and another of the same missionary genre, after a life of service to the church in South Africa:

I have been shaped in soul and mind by Africa. I feel comfortable with this shape and enjoy the feel of it.

I have walked alongside some incredible people, been partner to moments of trusting friendship, been called brother by people who made the naming feel good, laughed and cried with many and simply wallowed in the wonder of loving and supportive friendship.

I believe in people and that the greatest gift we can give others is to relate to other people for who they are and not for what they are.

I am a Christian. I believe that there is a God of love at the core of all things. I believe that this God wants us to be in community with him and thereby in community with one another. 
I believe in Jesus Christ as the communication of God to show these two core beliefs to be true.

I am committed to my church despite the rocky path our relationship has taken over the years and I will serve its people as best I can with what energy still lies within my being. Respect means helping one another to be what we are meant to be: human with all the possibilities, vulnerabilities and challenges to great heights that it may include. Anything that stands in the way of that potential of being human is, for me, the anti-Christ.

Bill was not one of those missionaries who sought to 'advance the gospel by supplying the indigenous people with human rights and personal freedoms' (Harries 2007,81 ). Born and nurtured among them, by them, he was committed to assisting them to rediscover these values in a context where they had been systematically deprived of them. His life witness compels us to come face to face with the reality of the future in our past. It is also an opportunity for recognising how much of the future we dream; its triumphs and low points as well as its possibilities are heralded, signified and captured and imagined in the life of persons like him.

\section{REFERENCES}

Allen, J. 2006. Rabble-Rouser for peace: The authorised biography of Desmond Tutu. Johannesburg: Random House.

Biko, S.B. 2004 [1978]. I write what I like. Johannesburg: Picador.

Bill, J-F. 1966. The responsible selfhood of the church: A study of the Tsonga Presbyterian Church. Chicago: Chicago Theological Seminary (unpublished).

Bill, J-F. 1977. Statement of purpose and historical narrative (speech made at opening of Albert Luthuli College, Federal Theological Seminary of Southern Africa 15 March 1977). François Bill Papers, Alan Paton Centre, Pietermaritzburg: University of KwaZulu-Natal.

Bill, J-F. and Russell, D, 1973. A pilgrimage of concern for family life. Agape: The Magazine of the Federal Theological Seminary of Southern Africa. 1(10), September): 19-22.

Bill, M. and J-F., Schneider, C. and T. 1972. Letter to all fraternal workers in the TPC, December 1972. University of Witwatersrand, William Cullen Library, 1084 File SIO [5].

Bonhoeffer, D. 1959. The cost of discipleship. London: SCM.

Cameron, R.D.T. 1984. Some political, ecumenical and theological aspects of the history of the Federal Theological Seminary: 1963-1975. Cape Town: UCT (unpublished).

Denis, P. and Duncan, G.A. 2011. The native school that caused all the trouble: A history of the Federal Theological Seminary of Southern Africa. Pietermaritzburg: Cluster.

Federal Theological Seminary. 1980. University of Fort Hare: Report of the sub-Committee for the Administration of the Seminary presented to the Council on 26 March 1980.

Harries, P. 2007. Butterflies and barbarians: Swiss missionaries and systems of knowledge in south-east Africa. Johannesburg: Wits University Press

Jeanneval, C., Monier-Gerard, E. and Peclav, D. 2011. Embroiled: Swiss churches, South Africa and apartheid. Berlin: Lit Verlag, Dr W. Hopf. 
Kairos Theologians 1986. The Kairos Document: Challenge to the church-a theological comment on the political crisis in South Africa. Braamfontein: Skotaville.

Kairos. 1986. Kairos liturgies for Good Friday and Easter Sunday. Braamfontein: Southern Transvaal Kairos Liturgy Group.

Kelly, G.B. and Nelson, F.B. 2003. The cost of moral leadership: The spirituality of Dietrich Bonhoeffer. Grand Rapids: Eerdmans.

Knighton-Fitt, J. 2003. Beyond fear. Cape Town: Pretext.

Lubbe, G. 2014. Embraced by grace: The story of a white ant. Honeydew: Potlaka Books.

Makue, E. 2008. Preface. In Justice and righteousness like a never-ending stream. Edited by E. Makue and T.S. Maluleke. 2008. Johannesburg: SACC, ix-x.

Maluleke, T.S. 1993. Mission, ethnicity and homeland: The Case of the EPCSA. Missionalia 21(3, November): 236-252.

Maluleke, T.S. 1994. North-south partnerships: The Evangelical Presbyterian Church in South Africa and the Department Missionary in Lausanne. International Review of Mission LXXXIII(328 January): 93-100.

Maluleke, T.S. 2005a. Jean- François Bill: Pastor, activist and theologian.

http://www.sacc.org.za/ARCHIVED\%20SACCNEWS/news05/billobit.html (accessed on 12 December 2006).

Maluleke, T.S. 2005b. Of mustard seed and yeast - the rock and the quarry: Remembering JeanFrançois Bill. Funeral oration delivered at the funeral service of Rev. Dr Jean- François Bill, Saturday 19 March 2005, Polokwane, South Africa.

Maluleke, T.S. 2008. Going back to him outside the camp. In Justice and righteousness like a never-ending stream. Edited by E. Makue and T.S. Maluleke. Johannesburg: SACC, xiii-xix.

McQueen, A.J .1998. Oberlin Alumni News and Notes, Spring. http://www.oberlin.edu/alummag/ oampast/oam_spring98/Alum_n_n/eduardo.html (accessed on 10 April 2016).

Mgojo, K.M. Service to the EPCSA - His church. http://www.sacc.org.za/ARCHIVED\%20 SACCNEWS/news05/billobit.html (accessed on 12 December 2006).

Mosala, I.J. and Thagale, B. 1986. The unquestionable right to be free. Braamfontein: Skotaville.

Nuttall, T. 2002. From pressure group to liberation organisation, 1979-1990. In Hope beyond apartheid: The Peter Kerchoff years of PACSA. Edited by L. Levine. Pietermaritzburg: PACSA.

Maré, G. and Hamilton, G. 1987. An appetite for power: Buthelezi's Inkatha and South Africa. Johannesburg: Ravan.

Phaswana, N.P. and Lilje, D. 2008. Foreword. In Justice and righteousness like a never-ending stream. Edited by E. Makue and T.S. Maluleke. 2008. Johannesburg: SACC, xi-xii.

Reformed Presbyterian Church in Southern Africa (RPCSA). 1988. Proceedings of the sixty-fifth General Assembly. Lovedale: Lovedale Press.

Robertson, R. 1999. St Antony's activists: Turning dreams into deeds. Cape Town: Robertson.

Said, E.W. 1999. Out of place: A memoir. London: Granta Books.

South African Council of Churches 1985. June 16 Memorial Service - A theological rationale and a call to prayer for the end of unjust rule. (Cape Town: Western Cape Council of Churches). 
Spong, B. 2006. Sticking around. Pietermaritzburg: Cluster.

Stults, D.leR. 2009. Grasping truth and reality: Lesslie Newbigin's theology of mission to the Western world. Cambridge: James Clarke and Co.

Van Butselaar, J. 1984. Missionaires et Colonialistes. Les origins de l'Église Presbytérienne du Mozambique (Mission Suisse), 1880-1896. Leiden: Brill.

Van Der Water, D. 2015. Social struggle and faith-based activism in black empowerment times. Missionalia 43(1, April): 7-22.

Yates, A. and Chester, L. 2006. The troublemaker Michael Scott and his lonely struggle against injustice. Johannesburg: STE Publishers. 